\section{Planting Methods Affect Early Growth and Root Distribution of Muscadine Vines}

\author{
William C. Olien', C.P. Hegwood, Jr' ${ }^{2}$ and James M. Spiers \\ U.S. Department of Agriculture, Agricultural Research Service, Small Fruit \\ Research Station, P. O. Box 287, Poplarville, MS 39470
}

Additional index words. Vitis rotundifolia, grape, root pruning, fine sandy loam, silt loam, peat amendment, planting hole

\begin{abstract}
Muscadine (Vitis rotundifolia Michx.) vineyards can be difficult to establish due to poor vine growth or survival during the first year after planting. Effects of the planting hole (five types), root manipulation (three levels), and peat amendment ( $0 \%$ and $50 \%$ ) on first-year growth were studied at two sites with different soil types: a sandy loam (welldrained) and a silty loam (moderately well-drained). The planting hole had the major effect at both sites; large holes ( 25 liters) shoveled with straight or angled sides resulted in more shoot and root dry weight and greater total root length than auger holes (21 liters) or small shovel holes (10 liters). Vine response to planting in a subsoil slot $0.5 \mathrm{~m}$ deep $\times 6$ $\mathrm{m}$ long was similar to that in large holes in sandy soil and small holes in heavier soil. Root manipulation treatments had little effect on vine establishment. Root pruning at planting, with or without root separation, did not increase vine dry weight relative to an undisturbed root ball in either soil type, but total root length was increased by root pruning in the heavier silty loam soil. Peat amendment increased total root length in the sandy soil but not in the silty loam soil.
\end{abstract}

The cost of establishing a vineyard is considerable and must be offset by fruit production as soon after planting as possible. Establishing muscadine vineyards, including site preparation, trellis, irrigation system, vines, labor, and first season vineyard maintenance, has been estimated to cost $\$ 8650 /$ ha (Bateman et al., 1987). More than 75 years ago, Husmann and Dearing (1916) observed that muscadine vines have "difficulty in starting," and poor establishment is still a frequent and costly problem for growers (Olien, 1990). Although several muscadine production manuals have recommended planting methods [Hegwood et al., 1983; Newman, 1907; Poling et al., 1985; U.S. Dept. of Agriculture (USDA)-Agricultural Research Service (ARS), 1973], there have been no published results of controlled studies comparing the effects of various planting methods.

Holes prepared for planting muscadine grapes vary considerably in size, shape, and digging method among growers. Planting holes for muscadine grapes are commonly dug with a shovel or a tractor-driven auger. Shovel-dug holes are often no larger than the width of a shovel blade. Tractor-driven augers create holes with smooth, polished walls that are

\footnotetext{
Received for publication 14 Dec. 1992. Accepted for publication 8 June 1993. The cost of publishing this paper was defrayed in part by the payment of page charges. Under postal regulations, this paper therefore must be hereby marked advertisement solely to indicate this fact.

${ }^{1}$ To whom reprint requests should be addressed. Current address: Dept. of Horticulture, Clemson Univ., Clemson, SC 29634-0375.

${ }^{2}$ Truck Crops Branch Experiment Station, Mississippi State Univ., P.O. Box 231, Crystal Springs, MS 39059.
}

known to restrict the growth and root distribution of fruit trees (Auxt et al., 1980). Conversely, work with landscape trees has shown that wide holes, especially with outwardly sloping rather than vertical walls, increase lateral root and total tree growth (Watson, 1986).

The degree of root manipulation at planting is a second important factor in successfully transplanting plants. Separating, pruning, and spreading roots in the hole has been a longrecommended planting procedure for muscadine grapes (Dearing, 1947; Hegwood et al., 1983; Husmann and Dearing, 1913; Newman, 1907). Failure to prune and spread roots occasionally has been suspected as the cause of poor vine establishment.

Soil organic matter content in the planting hole is a third factor affecting the establishment of many transplants, but it has not been evaluated for muscadine. Deficient soil humus has long been recognized as a common limitation of southern U.S. farmland (Husmann and Dearing, 1913). Peat amendment is commonly recommended when planting woody landscape plants and blueberries (Vaccinium ashei Reade) (e.g., Perry, 1985; Spiers et al., 1985), but has not been recommended for planting muscadine.

Our objective in this study was to evaluate the effects of planting methods on first-year shoot and root growth of newly planted muscadine vines. Two sites, representing two soil types common in muscadine production areas, were selected to evaluate three planting variables: 1) planting hole type, 2) root manipulation, and 3) peat amendment.

Study sites and soil types: Sandy loam site. Planting methods were evaluated at the USDA Small Fruit Research Station in Poplarville,
Miss., on an eroded Ruston fine, sandy loam soil (fine-loamy, siliceous, thermic Typic Paleudults) with a $2 \%$ slope (Nichols et al., 1983). The A horizon is $\approx 30 \mathrm{~cm}$ deep, below which the $\mathrm{B}$ horizon is present as a red sandy clay loam $\approx 1 \mathrm{~m}$ thick. This soil type is well drained, with an average organic matter content (OMC) from $0.5 \%$ to $2.0 \%(\mathrm{w} / \mathrm{w})$ over the $\mathrm{A}$ and $\mathrm{B}$ horizons. This site had been used previously for small fruit production, but not for muscadine grapes. Before planting, the soil was limed, disked, rototilled, and fumigated with methyl bromide, followed by construction of a two-wire vertical trellis.

Silty loam site. Planting treatment effects also were evaluated in a moderately welldrained site at the Mississippi State Univ. Truck Crops Branch Experiment Station in Crystal Springs. Soil type at this site is a Providence silty loam (fine to silty, mixed, thermic Typic Fragiudalfs), with a 2\% to 5\% slope (Milbrandt, 1984). The A horizon is 15 $\mathrm{cm}$ deep, and the average OMC for the A and B horizons varies from $0.5 \%$ to $3.0 \%$ (w/w). A Euvitis cultivar trial had been removed from this site, leaving Geneva double curtain trellises in place. The soil was rototilled, but not fumigated, before planting our trial.

Two-year-old vines, rooted from softwood cuttings and grown in 2-liter pots $(15 \mathrm{~cm}$ top diameter $\times 15 \mathrm{~cm}$ height) in a sand-vermiculite-pine bark mix, were obtained from a commercial nursery. Vines were planted 1-8 Apr. 1988 at Poplarville and 6 Apr. 1989 at Crystal Springs, with rows spaced $3.7 \mathrm{~m}$, and vines spaced $3.0 \mathrm{~m}$ in each row.

Planting procedure was based on recommendations given in muscadine production manuals (Ferree et al., 1983; Hegwood et al., 1983; Poling et al., 1985; USDA-ARS, 1973) and was modified as described in the sections on planting treatments that follow. Unless otherwise stated, the vines were planted in large holes, with the prune-and-spread level of root manipulation, and without a $50 \%$ peat amendment to the planting hole soil (see treatments descriptions, which follow). Less than 2 liters of bark-based medium left from the nursery pots were incorporated into the soil as the vines were planted.

Fertilization practice and control of weeds, diseases, and insects followed vineyard management recommendations for Mississippi (Hegwood et al., 1983). Irrigation at the sandy loam site was provided by overhead sprinklers and at the silty loam site by drip irrigation, with one 8 -liter $\cdot h^{-1}$ emitter near the base of each vine.

Planting hole treatments. Five types of planting holes (three shovel-dug and two machine-dug) were evaluated. 1) Small, 10-liter holes with vertical sides $(\approx 23 \mathrm{~cm}$ in diameter $\times 25 \mathrm{~cm}$ deep) were dug with a standard shovel. 2) Large, 25-liter shovel holes were dug with vertical sides $[36 \mathrm{~cm}$ in diameter (more than twice the diameter of the nursery pot) $\times 25 \mathrm{~cm}$ deep]. 3) Angled shovel holes with sloping sides equaled the Large holes in volume, but differed in geometry and were prepared in two steps. A 25-cm-deep shovel hole was dug with atop diameter of $50 \mathrm{~cm}$ and 
Production \& Culture

base diameter of $20 \mathrm{~cm}$, creating walls that sloped $60^{\circ}$ from horizontal. The walls were then roughened to avoid polished surfaces and promote root growth out of the hole and into the native soil. 4) Auger holes were dug with a 30-cm-diameter tractor-driven auger to a depth of $30 \mathrm{~cm}$ (21-liter volume). 5) For subsoil, a trench was dug $(3 \mathrm{~cm}$ wide $\times 6 \mathrm{~m}$ long $\times 50 \mathrm{~cm}$ deep or less). About $1 \mathrm{~m}$ on each end of the 6-m-long plot was required to lower and raise the subsoiler from full depth.

Root manipulation treatments. Treatments consisted of None, Cuts, and prune and Separate $(\mathrm{P} \& S)$. In None, the intact ball of roots and potting medium was planted directly from the pot with no root manipulation. For Cuts, three equally spaced radial cuts were made to the root ball (parallel to the trunk axis) to sever circling roots. $\mathrm{P} \& S$ represented a maximum level of root manipulation and was accomplished in several steps. All pot medium was removed, and care was taken to keep the root system wet, preventing desiccation during subsequent handling. The roots were combed and straightened by hand to prevent tangling and circling and to promote new root growth by thinning and wounding some of the fine roots. The root system was then pruned to 20 $\mathrm{cm}$, spread in the planting hole, and the hole was filled with soil.

Peat amendment treatments. Vines were planted without (- peat) or with (+ peat) $50 \%$ $(\mathrm{v} / \mathrm{v})$ peat amendment to the planting hole soil. Initial and final OMC were determined at the sandy loam site from dry and ash weights (Horwitz, 1980) of soil samples collected from the planting hole area.

Design and analysis. At the sandy loam site, main effects of the three planting variables were evaluated in separate randomized complete block studies with single vine plots. Availability of vines did not permit the use of a single cultivar in these studies. The planting hole and root manipulation variables were each evaluated with 'Noble' in five replicate blocks. Peat amendment treatments were compared over eight replications, blocked over 'Hunt', 'Roanoke', 'Scuppernong', and 'Sterling' (two replications of each cultivar). At the silty loam site, all three planting variables were randomized within eight replicate blocks of 'Summit'. Data were tested by analysis of variance, and means were compared by logical contrasts.

Destructive vine harvest. At both sites, dormant vines were harvested destructively at the end of the first growing season to determine total vine growth and root distribution in the soil. Dry weights were recorded after becoming constant at $70 \mathrm{C}$. Total leaf dry weight was determined at the sandy loam site in Sept. 1988, shortly before onset of leaf senescence and abscission. Destructive vine harvest was 1-9 Dec. 1988 at the sandy loam site and 2728 Feb. 1990 at the silty loam site. The aboveground portion of the vine (trunk and shoots) was collected to obtain dry weight. The root system then was excavated carefully by hand from the soil, and the vertical and horizontal root distribution was mapped. Length, orientation, and position of each coarse root $(\geq 2 \mathrm{~mm}$

Table 1. Effects of planting methods on total root length.

\begin{tabular}{|c|c|c|c|c|c|c|}
\hline \multirow{3}{*}{$\begin{array}{l}\text { Planting } \\
\text { treatments }\end{array}$} & \multicolumn{6}{|c|}{ Coarse root length $(\mathrm{m})$} \\
\hline & \multicolumn{3}{|c|}{ Sandy loam site } & \multicolumn{3}{|c|}{ Silty loam site } \\
\hline & Shallow & Vertical & Total & Shallow & Vertical & Total \\
\hline \multicolumn{7}{|l|}{ Planting hole } \\
\hline Large (A) & 8.5 & 0.63 & 9.1 & 11.2 & 2.2 & 13.4 \\
\hline Angled (B) & 8.8 & 0.62 & 9.4 & 8.9 & 1.7 & 10.6 \\
\hline Small (C) & 6.6 & 0.39 & 6.9 & 5.9 & 2.5 & 8.4 \\
\hline Auger (D) & 6.5 & 0.57 & 7.1 & 8.7 & 1.7 & 10.4 \\
\hline Subsoil (E) & 9.1 & 0.62 & 9.7 & 8.4 & 1.7 & 10.1 \\
\hline $\mathrm{AB} \times \mathrm{CD}$ & $* \mathrm{z}$ & * & * & * & NS & + \\
\hline $\mathrm{AB} \times \mathrm{E}$ & NS & NS & NS & NS & NS & NS \\
\hline $\mathrm{CD} \times \mathrm{E}$ & $*$ & * & * & NS & NS & NS \\
\hline$A \times B$ & NS & NS & NS & NS & NS & NS \\
\hline $\mathrm{C} \times \mathrm{D}$ & NS & ** & NS & NS & NS & NS \\
\hline \multicolumn{7}{|l|}{ Root manipulation } \\
\hline None & 7.5 & 0.54 & 8.0 & $7.7 \mathrm{~b}$ & 1.4 & $9.1 \mathrm{a}$ \\
\hline Cut ball & 5.8 & 0.53 & 6.4 & $9.5 \mathrm{ab}$ & 1.7 & $11.2 \mathrm{ab}$ \\
\hline Prune and spread & 7.2 & 0.53 & 7.7 & $11.2 \mathrm{a}$ & 2.2 & $13.4 \mathrm{~b}$ \\
\hline$F$ test & NS & NS & NS & $*$ & NS & $*$ \\
\hline \multicolumn{7}{|l|}{ Peat amendment } \\
\hline None & 6.3 & 0.54 & 6.8 & 11.2 & 2.2 & 13.4 \\
\hline $50 \%$ Peat & 7.7 & 0.52 & 8.3 & 10.8 & 1.9 & 12.7 \\
\hline$F$ test & NS & NS & + & NS & NS & NS \\
\hline
\end{tabular}

${ }^{z}$ Orthogonal contrasts of treatments within columns.

ss,+, Nonsignificant or significant at $P \leq 0.10$ or 0.05 , respectively.

in diameter) were recorded on the root map. Finally, total root dry weight was obtained.

General growth observations. Three vines died. One was a $\mathrm{P} \& \mathrm{~S}$ root manipulation vine planted at the sandy loam site, and the other two were planted in the Small planting holes at the silty loam site. Thus, while some vines died, the primary effects of the planting methods evaluated were on vine growth and root distribution. The shoot: root dry-weight ratio was not affected by planting treatment and averaged 1.9 for the sandy loam and 1.2 for the silty loam sites.

Overall, the root systems at both sites were comprised of extensive shallow, horizontally spreading roots, with a few vertically oriented roots extending more deeply into the soil profile. The extensive shallow roots were in the top 10 to $15 \mathrm{~cm}$ of soil, with some individual roots growing as long as $2.3 \mathrm{~m}$ by the end of the season. Vertical roots made up only $7 \%$ and $16 \%$ of total root length in the sandy loam and

Table 2. Effects of planting methods on dry weight distribution.

\begin{tabular}{|c|c|c|c|c|c|c|c|}
\hline \multirow[b]{3}{*}{$\begin{array}{l}\text { Planting } \\
\text { treatment }\end{array}$} & \multicolumn{7}{|c|}{ Vine dry wt components (g) } \\
\hline & \multicolumn{4}{|c|}{ Sandy loam site } & \multicolumn{3}{|c|}{ Silty loam site } \\
\hline & Leaf & Stem & Root & $\begin{array}{c}\text { Stem } \\
\text { and root } \\
\text { total }\end{array}$ & Stem & Root & $\begin{array}{c}\text { Stem } \\
\text { and root } \\
\text { total }\end{array}$ \\
\hline \multicolumn{8}{|l|}{ Planting hole } \\
\hline Large (A) & 146 & 201 & 92 & 293 & 178 & 141 & 319 \\
\hline Angled (B) & 192 & 249 & 107 & 356 & 136 & 113 & 249 \\
\hline Small (C) & 126 & 168 & 80 & 249 & 101 & 94 & 195 \\
\hline Auger (D) & 129 & 167 & 79 & 246 & 111 & 93 & 204 \\
\hline Subsoil (E) & 155 & 213 & 98 & 312 & 100 & 91 & 191 \\
\hline $\mathrm{AB} \times \mathrm{CD}$ & $* z$ & $*$ & * & $*$ & $*$ & $*$ & * \\
\hline $\mathrm{AB} \times \mathrm{E}$ & NS & NS & NS & NS & * & NS & * \\
\hline $\mathrm{CD} \times \mathrm{E}$ & + & + & $*$ & $*$ & NS & NS & NS \\
\hline$A \times B$ & $*$ & + & NS & + & NS & NS & NS \\
\hline$C \times D$ & NS & NS & NS & NS & NS & NS & NS \\
\hline \multicolumn{8}{|l|}{ Peat amendment } \\
\hline None & 88 & 108 & 67 & 175 & 178 & 141 & 319 \\
\hline $50 \%$ Peat & 130 & 167 & 99 & 265 & 161 & 124 & 285 \\
\hline$F$ test & NS & + & + & + & NS & NS & NS \\
\hline
\end{tabular}

${ }^{2}$ Orthogonal contrasts of treatments within columns.

${ }_{\mathrm{N},+,+}{ }^{*}$ Nonsignificant or significant at $P \leq 0.10$ or 0.05 , respectively. silty loam sites, respectively (Table 1). Vertical roots usually originated near the crown, but also occurred farther out as branches from the shallow roots. This pattern of root distribution is similar to that reported for 5-year-old 'Nobel' muscadine grapes in a deep, fine sandy soil in Texas (Perry et rd., 1983).

Effects of the planting hole. At both sites, large shovel-dug holes with straight or angled walls resulted in dramatically improved vine growth relative to small shovel- or auger -dug holes (Tables 1 and 2). Final dry weights of all vine components were increased by the larger holes, with no difference in the shoot : root dry-weight ratio (Table 2). Superiority of large and angled holes over small and auger holes also was evident in greater shallow and total coarse root length at both sites, and in greater vertical coarse root length at the sandy loam site (Table 1).

Vines in the angled holes performed somewhat better than vines in the large holes in 
sandy soil, but not in the heavier silty loam. Vines in the angled holes developed more leaf, stem, and total dry weight than vines in the large holes at the sandy site (Table 2). These results are similar to those obtained with landscape trees, where wide holes with angled walls improved shallow root growth and total growth over trees planted in standard holes with straight sides (Watson, 1986). Thus, the angled hole may be the best choice in light, well-drained soils.

In comparing the two small-hole types, vertical coarse root length was significantly greater for auger- than for small shovel-dug holes (Table 1), but there were no other significant differences in dry weights or root lengths between these two treatments. Vines planted in the subsoil slot responded similarly to those in the two large-hole types in the sandy loam, but were intermediate or similar in response to those in the two small-hole types in the silty loam (Tables 1 and 2). Above-ground and total dry weights of vines planted in subsoil slots were similar to those of the two large-hole types in sandy soil and to those in the two restrictive hole types in silty loam (Table 2). Shallow and vertical coarse root lengths in the subsoil treatment were similar to those in the two large-hole types in sandy soil, and statistically not different from roots in either the two large- or the two small-hole types in silty loam (Table 1). The subsoil blade may have created a polished soil interface in the heavier silty soil that did not occur in the sandy soil, thus restricting root growth in the silty soil. This effect would be similar to the polished soil surface that develops in auger-dug holes (Auxt et al., 1980).

Effects of root manipulation. The three levels of root manipulation did not affect shoot or root dry weight in either soil type, averaging 206 and $207 \mathrm{~g}$ total vine dry weight in the sandy loam and silty loam sites, respectively. However, in the heavier silty loam site, there was a significant increase in shallow and total coarse root length with increasing severity of root manipulation (Table 1). These results are similar to those reported for root manipulation effects on pecan [Carya illinoinensis (Wangenh.) C. Koch] trees (Laiche et al., 1983).

Effects of peat amendment. There was no significant interaction between the peat amendment treatments and the four cultivars used in the sandy loam study, so results were pooled over cultivars. Peat amendment at the sandy site appeared to increase stem, root, and total vine dry weight (Table 2), and total root length (Table 1), but these differences were signifi- cant only at $P \leq 0.10$. There were no significant differences due to peat amendment at the silty loam site.

The OMC of both the nonamended sandy loam and silty loam soils was $1.5 \%$ (w/w). Peat amendment of sandy loam soil initially increased the OMC to $12.3 \%$, but by the end of the season, OMC in peat-amended holes had declined to $2.4 \%$. Decomposition of soil organic matter is rapid in the hot summers that are typical of the southeastern United States (Husmann and Dearing, 1913). Rates of peat amendment $>50 \%$ may be required to maintain large differences in the OMC of southeastern sandy loam soils throughout the season.

Conclusions. The shallow, spreading root systems of muscadine grapes make planting practices affecting horizontal root growth especially important for strong growth of muscadine vines during establishment. Planting practices that gave best vine growth differed somewhat between a well-drained fine sandy loam soil and a moderately well-drained silty loam soil. The most important practice in both soil types was planting in a large hole. Large planting holes with straight or angled walls resulted in best vine growth, while small holes dug with a shovel or with a tractor-driven auger resulted in poorest vine growth at both sites. Planting in a subsoil slot was beneficial relative to planting in small holes in sandy soil, but not in heavier soil.

Root pruning and separation at planting had no effect on shoot or root growth in sandy soil, but total and shallow root length was increased by this practice at the silty loam site. Root pruning procedures recommended in muscadine production manuals have ranged from severe (Dearing, 1947; Husmann and Dearing, 1913; Newman, 1907) to only moderate (Hegwood et al., 1983; Savage et al., 1941 ). Root separation, pruning, and spreading of muscadine vines may be beneficial in heavier silty soils, but do not appear to be beneficial in lighter sandy loam soil. Peat amendment marginally increased vine dry weight and total root length in sandy soil, but not in silty loam soil. Overall, the size of the planting hole and the lack of polished or compressed side walls in the hole were the most important factors improving the establishment of muscadine vines.

\section{Literature Cited}

Auxt, T., S. Blizzard, and K. Elliot. 1980. Comparison of apple planting methods. J. Amer. Soc. Hort. Sci. 105:468-472.
Bateman, L., C.R. Sollie, and J. Stenmark. 1987. Alternative enterprises for farmers: A case study of the muscadine. Southern Rural Dev. Ctr. Bul. 105.

Dearing, C. 1947. Muscadine grapes. U.S. Dept. of Agr. Farmers' Bul. 1785.

Ferree, M.E., R.M. Crassweller, and G.W. Krewer. 1983. Commercial muscadine grape culture. Georgia Coop. Ext. Serv. Bul. 739.

Hegwood, C.P., R.H. Mullenax, R.A. Haygood, T.S. Brook, and J.L. Peeples. 1983. Establishment and maintenance of muscadine vineyards. Mississippi State Univ., Coop. Ext. Serv. Bul. 913.

Horwitz, W. (ed.). 1980. Official methods of analysis. 13th ed. Assn. of Offic. Anal. Chemists, Washington, D.C.

Husmann, G.C. and C. Dearing. 1913. The muscadine grapes. U.S. Dept. of Agr., Bur. Plant Industry Bul. 273.

Husmann, G.C. and C. Dearing. 1916. Muscadine grapes. U.S. Dept. of Agr. Farmers' Bul. 709.

Laiche, A.J., Jr., W.W. Kilby, and J.P. Overcash. 1983. Root and shoot growth of field- and container-grown pecan nursery trees five years after transplanting. HortScience 18:328-329.

Milbrandt, A.C. 1984. Soil survey of Copiah County Mississippi. U.S. Dept. of Agr., Soil Conservation Serv.

Newman, C.C. 1907. Rotundlfolia grapes. South Carolina Agr. Expt. Sta. Bul. 132.

Nichols, P., Jr., A.R. Leggett, and L.B. Walton. 1983. Soil survey of Pearl River County Mississippi. U.S. Dept. of Agr., Soil Conservation Serv.

Olien, W.C. 1990. The muscadine grape: Botany, viticulture, history, and current industry. HortScience 25:732-739.

Perry, J. 1985. Transplanting ornamental trees and shrubs. Mississippi Coop. Ext. Serv. Info. Sheet 965.

Perry, R.L., S.D. Lyda, and H.H. Bowen. 1983. Root distribution of four Vitis cultivars. Plant \& Soil 71:63-74.

Poling, B., C.M. Mainland, and J.B. Earp. 1985. Muscadine grape production guide for North Carolina. North Carolina Agr. Ext. Serv. Bul. AG-94.

Savage, E.F., L. Ascham, T.L. Bissell, W.L. Brown, T.A. Pickett, W.A. Jenkins, M.M. Murphy, Jr., and J.G. Wcodroof. 1941. Further studies with the muscadine grape. Georgia Expt. Sta. Bul. 217.

Spiers, J.M., J.H. Braswell, and C.P. Hegwood, Jr. 1985. Establishment and maintenance of rabbiteye blueberries. Mississippi Agr. and For. Expt. Sta. Bul. 941.

U.S. Dept. of Agriculture-Agricultural Research Service. 1973. Muscadine grapes: A fruit for the South. U.S. Dept. of Agr. Farmers' Bul. 2157.

Watson, G.W. 1986. Cultural practices can influence mot development for better transplanting success. J. Environ. Hort. 432-34. 